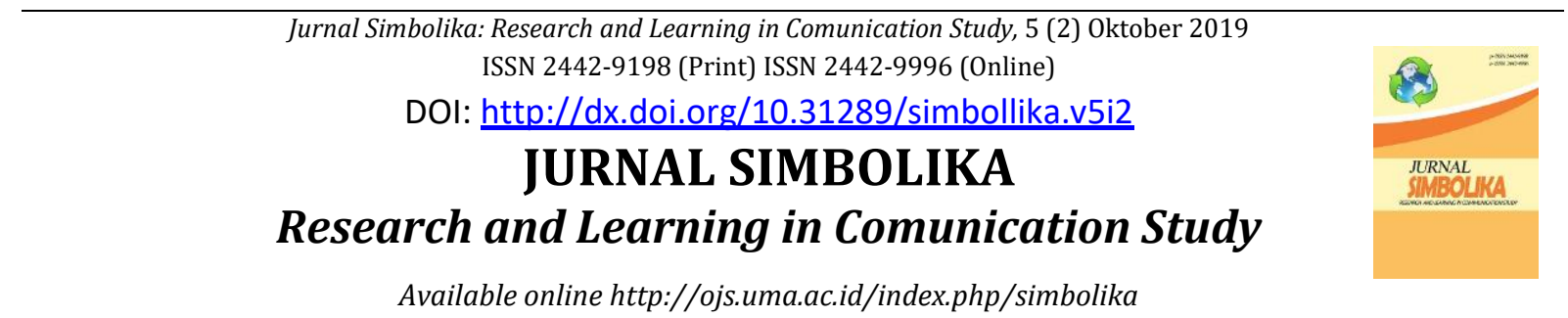

\title{
Filsafat Komunikasi dalam Makrokosmos
}

\section{Communication Philosophy in Macrocosmos}

\author{
Daryanto Setiawan \\ Program Studi Komunikasi Penyiaran Islam, \\ Sekolah Tinggi Agama Islam As Sunnah, Deli Serdang, Indonesia \\ Diterima: Agustus 2019 Disetujui: Oktober 2019 Dipublish: Oktober 2019 \\ *Coresponding Email: daryantosetiawan11@gmail.com
}

\begin{abstract}
Abstrak
Aliran behaviourisme merupakan aliran yang berjasa dalam munculnya keberadaan ilmu komunikasi. Behaviourisme merupakan derivasi dari positivisme yang berupaya mengidependisikan ilmu-ilmu dari filsafat dengan objek material dan objek formal masing-masing. Berkat dukungan behaviourisme dan positivisme itu komunikasi menjadi ilmu yang merdeka dari filsafat. Filsafat komunikasi adalah ilmu pengetahuan yang menelaah secara mendasar mengenai keilmuan komunikasi dari historisnya, teoriteorinya, metode-metodenya, prinsip-prinsip metodologi yang digunakan, sampai pada semua hal yang terkait pada cakupan komunikasi. Sedangkan makrokosmos adalahilmu yang membahas keseluruhan alam semesta. Terdapat perbedaan yang mendasar tentang alam antara pandangan filsafat Barat dengan pandangan filsafat Islam. Dalam pandangan filsafat Barat, alam terjadi dengan sendirinya (by nature). Sedangkan dalam pandangan filsafat Islam, alam terjadi karena ada yang menjadikan yaitu Allah. Tulisan ini menjelaskan bahwa ternyata alam semesta ini, baik biotik (tumbuhan, hewan, manusia) maupun abiotik (tanah, air, udara, dan sinar matahari) semuanya dapat berkomunikasi. Berkomunikasinya alam ini dijelaskan melalui penelitian ilmiah dan dipertegas lagi dari Alquran dan Hadist.
\end{abstract}

Kata Kunci: Filsafat; Filsafat Komunikasi; Makrokosmos

\begin{abstract}
The flow of behaviorism is a meritorious flow in the emergence of communication science. Behaviorism is a derivation of positivism that seeks to independent science from philosophy with material objects and formal objects respectively. Thanks to the support of behaviorism and positivism, communication becomes an independent science from philosophy. Communication philosophy is a science that examines fundamentally about the science of communication from its history, its theories, its methods, the methodological principles used, to all matters related to the scope of communication. Whereas macrocosm is a science that discusses the whole universe. There is a fundamental difference about nature between the views of Western philosophy and the views of Islamic philosophy. In the view of Western philosophy, nature happens by itself (by nature). While in the view of Islamic philosophy, nature occurs because there is what makes God. This paper explains that it turns out that the universe, both biotic (plants, animals, humans) and abiotics (earth, water, air, and sunlight) can all communicate. The communication of this nature is explained through scientific research and reinforced by the Qur'an and Hadith.
\end{abstract}

Keywords: Philosophy; Communication Philosophy; Macrocosmos.

How to Cite: Setiawan, D. (2019). Filsafat Komunikasi Dalam Makrokosmos. Jurnal Simbolika: Research and Learning in Comunication Study, 5 (2): 73-87 


\section{PENDAHULUAN}

Sebelum Perang Dunia II, kajian tentang komunikasi secara spesifik belum ada. Adalah aliran behaviourisme yang memungkinkan keberadaan ilmu komunikasi. Behaviourisme merupakan derivasi dari positivisme yang berupaya mengidependisikan ilmu-ilmu dari filsafat dengan objek material dan objek formal masing-masing. Berkat dukungan behaviourisme dan positivisme itu komunikasi menjadi ilmu yang merdeka dari filsafat (Maarif, 2016).

Pembaharuan ilmu terus-menerus dapat terjadi karena filsafat menggunakan rasio yang kritis, refleksif dan integral terhadap objek kajiannya. Filsafat tidak pernah puas dengan penampakan, melainkan secara kritis menerobos penampakan (fenomena) itu demi mencapai hakikat yang paling dasar atau kenyataannya sendiri. Filsafat mengedepankan kekritisan dalam membongkar asumsi, refleksi dalam mengedepankan apa saja yang diserap oleh indera untuk diolah oleh rasio dan radikal dalam mengupayakan pemahaman yang mendasar sampai ke akar-akarnya (Adian, 2002).

Untuk mengetahui arti filsafat komunikasi maka perlu dibahas terlebih dahulu tentang filsafat ilmu. Filsafat ilmu merupakan landasan pemikiran yang mendasar dari suatu ilmu untuk mencapai kebenaran. Berdasarkan literartur yang penulis baca, filsafat merupakan induk dari ilmu pengetahuan termasuk ilmu komunikasi.

Dalam tulisan ini, selain membahas tentang filsafat ilmu, filsafat ilmu komunikasi, penulis juga akan mengkaji tentang metafisika, kosmologi dan makrokosmos. Kemudian diakhiri dengan pembahasan filsafat komunikasi dalam makrokosmos berdasarkan pendapat para Filsuf Barat, Filsuf Islam dan keterangan dari Alquran dan Hadis terkait makrokosmos.

\section{PEMBAHASAN}

\section{Pengertian Filsafat}

Filasat dalam bahasa Inggris, yaitu: Philosopy, adapun istilah filsafat berasal dari bahasa Yunani: philosohia, yang terdiri atas dua kata: philos (cinta) atau philia (persahabatan, tertarik kepada) dan sophos (hikmah, kebijaksanaan, pengetahuan, keterampilan, pengalaman praktis, intelegensi). Jadi, secara etimologi, filsafat berarti cinta kebijaksanaan atau kebenaran (love of wisdom). Orangnya disebut filosof yang dalam bahasa Arab disebut failasuf (Bakhtiar, 2010).

Sedangkan secara terminologi filsafat adalah perenungan yang mendalam mengenai sesuatu yang dianggap atau 
dinilai bermanfaat bagi kehidupan manusia. Fisafat merupakan sebuah disiplin ilmu yang terkait dengan perihal kebijaksanaan. Kebijaksanaan itu sendiri merupakan butir ideal dalam kehidupan manusia. Melalui kebijaksanaan, manusia mampu bersikap dan bertindak atas dasar pertimbangan kemanusiaan yang tinggi, bukan asal bertindak sebagaimana yang biasa dilakukan masyarakat awam (Syams, 2013).

Al Farabi mendefinisikan filsafat ialah ilmu tentang alam yang maujud dan bertujuan menyelidiki hakikatnya yang sebenarnya (Anshari, 1987). Ibnu Rusyd berpendapat bahwa filsafat merupakan pengetahuan otonom yang perlu dikaji oleh manusia karena dia memiliki akal (Salam, 1988).

Pengertian filsafat secara terminologi sangat beragam, baik dalam ungkapan maupun titik tekanannya. Bahkan, Moh. Hatta dan Langeveld mengatakan bahwa definisi filsafat tidak perlu diberikan karena setiap orang memiliki titik tekan sendiri dalam definisinya. Oleh karena itu, biarkan saja seseorang meneliti filsafat terlebih dahulu kemudian menyimpulkan sendiri (Bakhtiar, 1997).

\section{Pengertian Ilmu}

Dalam Kamus Besar Bahasa Indonesia, ilmu yaitu pengetahuan tentang sesuatu bidang yang disusun secara bersistem menurut metode tertentu yang dapat digunakan untuk menerangkan gejala tertentu di bidang pengetahuan itu. Ilmu adalah pengetahuan tentang faktafakta baik natural maupun sosial yang berlaku umum dan sistematis (Sujarwo dan Basrowi, 2009).

Mohammad Hatta mendefinisikan bahwa ilmu adalah pengetahuan yang teratur tentang pekerjaan hukum kausal dalam suatu golongan masalah yang sama tabiatnya, maupun menurut kedudukannya tampak dari luar, maupun menurut bangunannya dari dalam (Anshari, 1987).

Sedangkan menurut Syukur Kholil, Ilmu adalah pengetahuan yang telah dirumuskan secara sistematis melalui berbagai penelitian atau percobaan yang dilakukan secara terus menerus, sehingga menemukan kebenaran yang bersifat universal. Tujuan ilmu adalah memberikan penjelasan terhadap gejala-gejala alam atau sosial secara cermat dan sistematis sehingga dapat dilakukan prediksi ke depan (Kholil, 2006).

Dari keterangan para ahli tentang ilmu di atas, penulis menyimpulkan bahwa 
ilmu adalah pengetahuan-pengetahuan yang memiliki syarat dan kriteria seperti sistematis, objektif atau sesuai fakta, empiris bukan metafisis, universal, dan dapat dilakukan prediksi ke depan.

Berdasarkan uraian di atas tentang filsafat dan ilmu, maka dapat disimpulkan bahwa filsafat ilmu merupakan kajian secara mendalam tentang dasar-dasar ilmu, sehingga filsafat ilmu perlu menjawab beberapa persoalan (Bakhtiar, 2010)

Pertanyaan landasan ontologis, objek apa yang ditelaah? Bagaimana wujud yang hakiki dari objek tersebut? Bagaimana korelasi antara objek tadi dengan gaya tangkap manusia (seperti berpikir, merasa, dan menindera) yang menghasilkan ilmu? Dari landasan ontologis ini adalah dasar untuk mengklasifikasi pengetahuan dan sekaligus bidang-bidang ilmu.

Pertanyaan landasan epistemologis, bagaimana proses pengetahuan yang masih berserakan dan tidak teratur itu menjadi ilmu? Bagaimana prosedur dan mekanismenya? Hal-hal apa yang harus diperhatikan agar kita mendapatkan pengetahuan yang benar? Apa yang disebut dengan kebenaran itu sendiri? Apakah kriterianya? Cara atau teknik atau sarana apa yang membantu kita dalam mendapatkan pengetahuan yang beruapa ilmu?
Pertanyaan landasan aksiologis, untuk apa pengetahuan yang berupa ilmu itu dipergunakan? Bagaimana kaitan antara cara penggunaan tersebut dengan kaidah-kaidah moral? Bagaimana penentuan objek dan metode yang ditelaah berdasarkan pilihan-pilihan moral? Bagaimana korelasi antara teknik procedural yang merupakan operasionalisasi metode ilmiah dengan norma-norma moral.

Pengertian Komunikasi, secara bahasa (etimologi) istilah komunikasi dalam bahasa Inggris disebut communication berasal dari kata Latin communicatio dan bersumber dari kata communis yang berarti sama. Sama di sini maksudnya adalah sama makna. Jadi, kalau ada dua orang terlibat dalam komunikasi, misalnya dalam bentuk percakapan, maka komunikasi akan terjadi atau berlangsung selama ada kesamaan makna mengenai apa yang dipercakapkan (Effendi, 2011).

Adapun secara terminologi komunikasi adalah proses penyampaian suatu proses pernyataan kepada orang lain untuk memberi tau atau merubah sikap, pendapat atau prilaku, baik langsung secara lisan maupun tak langsung melalui media (Effendi, 1999). Kemudian menurut William C. Himstreet dan Wayne Murlin Baty, komunikasi adalah suatu proses pertukaran infomasi atara individu melalui 
suatu sistem yang biasa (lazim), baik dengan simbol-simbol, sinyal-sinyal maupun prilaku atau tindakan (Purwanto, 2003).

Menurut John Fiske, komunikasi adalah salah satu dari aktivitas manusia yang dikenali oleh semua orang namun sangat sedikit yang dapat mendefinisikannya secara memuaskan. Komunikasi memiliki variasi definisi yang tidak terhingga seperti; saling berbicara satu sama lain, televisi, penyebaran informasi, gaya rambut kita, kritik sastra, dan masih banyak lagi (Fiske, 2012).

Karena begitu luasnya masalah komunikasi ini, hingga kini terdapat ratusan definisi komunikasi yang telah dikemukakan para ahli. Seringkali suatu definisi komunikasi berbeda atau bahkan bertentangan dengan definisi lainnya. Tahun 1976 saja Fank Dance dan Carl Larson telah mengumpulkan 126 definisi komunikasi yang berlainan (Mulyana, 2001).

Dari beberapa definisi di atas, menunjukkan bahwa meskipun para ahli dalam mendefinisikan komunikasi dengan cara yang berbeda-beda akan tetapi apa yang telah mereka kemukakan tentang definisi komunikasi pada dasarnya mempunyai penekanan arti yang sama, saling melengkapi dan menyempurnakan makna komunikasi sejalan dengan perkembangan ilmu komunikasi.

\section{Pengertian Filsafat Komunikasi}

Secara sederhana filsafat komunikasi jika di hubungkan dengan kata ilmu memiliki arti yaitu suatu filsafat yang mencoba mengkaji ilmu komunikasi dari ciri-ciri dan cara-cara memperolehnya. Jadi filsafat ilmu memberikan sejumlah pertanyaan terhadap ilmu tersebut agar ilmu itu berkembang, berada dalam kerangka yang lebih luas, memilki hubungan dengan ilmu-ilmu lain, dan dapat menjadi sistematis dan memiliki kebenaran. Filsafat ilmu komunikasi di antaranya akan memberikan pertanyaan: Bagaimana ilmu komunikasi dapat berkembang? Siapa yang menentukan arah perkembangan ilmu komunikasi? Bagaimana ilmu komunikasi dapat muncul? Apakah kemunculan ilmu komunikasi merupakan suatu kebetulan saja dan merupakan gejala historis? Apakah ilmu komunikasi memiliki suatu metode yang sama dengan ilmu lainnya? (Ardianto dan Q-Anees, 2011).

Muhammad Mufid menjelaskan bahwa filsafat komunikasi adalah ilmu yang mengkaji setiap aspek dari komunikasi dengan menggunakan pendekatan dan metode filsafat sehingga 
didapatkan penjelasan yang mendasar, utuh, dan sistematis seputar komunikasi (Mufid, 2009).

Berdasarkan uraian di atas penulis memberikan kesimpulan bahwa filsafat komunikasi adalah suatu pengetahuan yang menelaah secara mendasar mengenai keilmuan komunikasi dari historisnya, teori-teorinya, metode-metodenya, prinsip-prinsip metodologi yang digunakan, sampai pada semua hal yang terkait pada cakupan komunikasi.

\section{Metafisika, Makrokosmos}

\section{Kosmologi,}

Metafisika merupakan filsafat yang pertama dan yang paling utama. Istilah metafisika berasal dari bahasa Yunani, meta dan taphisica, diartikan sebagai yang ada di balik atau di belakang benda-benda fisik. Aristoteles tidak menggunakan istilah metafisika, tetapi proto philosophia (filsafat pertama). Metafisika di katakan filsafat pertama karena metafisika membuat uraian tentang sesuatu yang ada di belakang gejala-gejala fisik seperti: bergerak, berubah, hidup, dan mati. Metafisika juga dapat didefinisikan sebagai studi atau pemikiran tentang sifat yang terdalam (ultimate nature) dari kenyataan atau keberadaan (Syams, 2013).

Cristian Wolff mengklasifikasikan metafisika, sebagai berikut: 1) Metafisika Umum (ontologi) membincarakan tentang hal "ada". 2) Metafisika Khusus yaitu: a. Psikologi dan Antropologi: membicarakan tentang hakikat manusia; b. Kosmologi: membicarakan tentang hakikat atau asalusul alam semesta; c. Teologi: membicarakan hakikat keberadaan Tuhan.

Berdasarkan pengklasifikasian di atas yang dikemukan oleh Christian Wolff, maka metafisika terbagi menjadi dua jenis yaitu metafisika umum dan metafisika khusus. Pada tulisan ini penulis tidak mengkaji jenis metafisika umum namun penulis akan membahas metafisika khusus yang lebih dititikberatkan pada pembahasan kosmologi.

Apa itu kosmologi? Dalam Kamus Besar Bahasa Indonesia kosmologi adalah 1) Ilmu (cabang astronomi yang menyelidiki asal-usul, struktur, dan hubungan ruang waktu dari alam semesta; 2) Ilmu tentang asal usul kejadian bumi, hubungannya dengan sistem matahari, serta hubungan sistem matahari dengan jagat raya; 3) Ilmu (cabang dari metafisika) yang menyelidiki alam semesta sebagai sistem yang beraturan.

Menurut Nina W. Syam, kosmologi berasal dari bahasa Inggris yaitu cosmology; dari bahasa Yunani, yaitu kosmos (dunia, alam semesta) dan logos (ilmu). Jadi, kosmologi adalah ilmu yang memandang alam semesta sebagai suatu keseluruhan yang integral. Kosmologi 
adalah ilmu yang mempelajari struktur dan sejarah alam semesta berskala besar yang mana secara umum ilmu ini dipelajari dalam astronomi, filosofi, dan agama (Syams, 2013).

Ahmad Zakaria Zain, mengemukakna bahwa kosmologi ialah "cosmology is a branch of philoshophy which treats of the origin and structure of the universe" artinya kosmologi adalah cabang ilmu filsafat yang membicarakan asal mula atau sejarah yang berkaitan dengan struktur alam semesta (Zain, 1876).

Menurut Notonagoro, kosmologi membahas alam semesta ditinjau dari dua sudut: a) Alam semesta ditinjau dari sudut keseluruhan, yang menyangkut pembicaraan tentang: 1) Masalah tertib alam semesta, 2) Masalah asal mula alam semesta, 3) Masalah kesempurnaan alam semesta; b) Alam semesta ditinjau dari sudut unsur-unsurnya meliputi: 1) Benda mati atau dunia an-organis, 2) Benda hidup atau dunia organis yaitu mencakup dunia tumbuh-tumbuhan, mencakup dunia hewan dan mencakup dunia manusia (Zain, 1876).

Berdasarkan uraian di atas, maka secara sederhana penulis dapat menyimpulkan bahwa arti dari kosmologi adalah suatu ilmu yang mempelajari tentang asal-usul terjadinya alam semesta.
Berdasarkan peryataan Notonagoro di atas, penulis menyimpulkan bahwa secara umum alam semesta atau jagad raya ini terbagi menjadi dua macam yaitu alam semesta yang membahaskeseluruhan alam semesta atau biasa disebut dengan istilah makrokosmos, dan alam semesta yang membahas tentang unsur-unsurnya seperti tumbuh-tumbuhan, hewan, dan manusia yang sering disebut dengan istilah mikrokosmos.

Jadi antara metafisika, kosmologi dan makrokosmos memiliki keterkaitan yang sangat erat sekali. Metafisika merupakan filsafat pertama yang didalamnya dikaji tentang kosmologi, sedangkan kosmologi itu sendiri merupakan ilmu yang membahas tentang makrokosmos (alam semesta).

\section{Filsafat Komunikasi dalam Makrokosmos}

Berdasarkan penjelasan di atas, maka yang dimaksud dengan filsafat komunikasi adalah suatu pengetahuan yang menelaah secara mendasar mengenai keilmuan komunikasi dari historisnya, teoriteorinya, metode-metodenya, prinsipprinsip metodologi yang digunakan, sampai pada semua hal yang terkait pada cakupan komunikasi. Filsafat komunikasi jika dihubungkan dengan makrokosmos bermakna yaitu pengetahuan yang 
menelaah secara mendasar mengenai keilmuan komunikasi dan keilmuan alam semesta yang dinilai bermanfaat bagi kehidupan manusia.

\section{Filsafat dengan Alam Semesta}

Terdapat perbedaan yang mendasar tentang alam antara pandangan filsafat Barat dengan pandangan filsafat Islam. Dalam pandangan filsafat Barat, alam terjadi dengan sendirinya (by nature). Sedangkan dalam pandangan filsafat Islam, alam terjadi karena ada yang menjadikan yaitu Allah.

Thales filsuf Yunani tertua yang berpendirian bahwa apa saja yang ada di alam ini asalnya tersusun dari air, menaruh keyakinan bahwa alam kodrat merupakan semacam makhluk hidup, sepertinya halnya hewan yang memiliki jiwa. Sedangkan Anaximander memandang subtansi terdalam sebagai sesuatu yang ia namakan "ketakterbatasan" yang digambarkannya bahwa hal tersebut tidak terhingga jumlahnya dan tidak tertentu sifatnya. Ia juga berpendapat bahwa atas dasar "ketidakterbatasan" tersebut maka timbulah bebagai dunia yang tidak terbatas jumlahnya (Kattsoff, 2004).

Leucippos pencetus teori atom, menjelaskan bahwa penciptaan alam semesta bermula dari beberapa atom yang berbeda bentuknya saling memisah dari masa yang tidak berbentuk dan berkumpul di dalam suatu ruang kosong yang maha luas. Setelah berkumpul, maka atom-atom tersebut membentuk suatu pusaran. Kemudian atom-atom tersebut saling berdesak-desak dimana atom-atom cahaya menetap pada bagian luar sedangkan atom-atom selebihnya tetap tinggal bersama. Atom-atom terakhir ini membentuk rangkaian yang tidak terputus, berbentuk seperti sabit dan membuat sejenis kulit luar yang disebut dengan langit. Pada pusatnya terdapat benda-benda yang terbentuk disana disana dan sekarang sudah saling memisahkan diri dimana sebagian ada yang terbang ke atas dan berkedudukan pada kulit luar. Inilah yang disebut dengan benda-benda langit. Sekarang semuanya bergerak mengelilingi massa-sentral yaitu materi yang darinya bumi dibentuk. Gerakan disebabkan karena mengeringnya massa sentral ini dan menguapnya air sehingga bumi dan laut terpisah (Zain, 1876).

Alam dalam sistem Aristoteles, terbatas oleh ruang tetapi tak terbatas oleh waktu, karena gerak alam seabadi Penggerak Tak Tergerakan. Keabadian alam, dalam pemikiran Islam ditolak karena Islam berpendirian bahwa alam diciptakan. Filsuf-filsuf Muslim dalam mengahadapi masalah ini mencoba mencari pemecahan yang sesuai dengan agama. Ibnu Sina dan Ibnu Rusyd dituduh 
atheis karena mereka sependapat dengan Aristoteles. Mereka berpendapat bahwa alam ini kekal (Syarif, 1993).

Alkindi yang merupakan filsuf yang pertama muncul di Islam (Supriyadi, 2009), menyatakan bahwa alam ini tidak kekal dan alam ini ada yang menciptakan. Ia membuktikan dengan mengajukan pertanyaan, "Mungkinkah sesuatu menjadi sebab bagi wujud dirinya ataukah tidak mungkin? Lalu dijawabnya sendiri, "Hal ini tidak mungkin karena tidak masuk akal sesuatu menciptakan dirinya sendiri". Dengan demikian, alam ini adalah baru dan mempunyai permulaan waktu. Oleh karena itu, alam ini terbatas. Selanjutnya, mesti ada penyebab terjadinya alam ini karena tidak mungkin ada benda yang ada dengan sendirinya. Sebab ini alam mestinya diciptakan oleh penciptanya dari tiada menjadi ada (Saefullah, 2013).

Al-Farabi mengatakan bahwa alam terjadi dengan tidak mempunyai permulaan dalam waktu (qadim), yaitu tidak terjadi secara berangsur-angsur, tetapi sekaligus tak berwaktu. Dia mencela orang yang mengatakan bahwa alam itu menurut Aristoteles adalah kekal.

Al-Ghazali dalam bukunya Tahafut alFalasifah (kekacauan para Filsuf), menurutnya orang yang mengatakan alam kekal dalam arti tidak bermula, tidak dapat diterima dalam teologi Islam. Dalam teologi Islam, Allah adalah Pencipta. Yang dimaksud pencipta adalah yang menciptakan sesuatu dari tiada menjadi ada. Jika alam dikatakan tidak bermula, alam bukanlah diciptakan. Dengan demikian, Allah bukanlah pencipta. Padahal dalam Alquran disebutkan bahwa Allah adalah pencipta segala-galanya.

Kritikan Al-Ghazali terhadap kaum Filsuf dijawab langsung oleh Ibnu Rusyd dalam karyanya Tahafut al-Falasafut (kekacauan dalam kekacauan). Menurut Ibnu Rusyd, pendapat kaum teolog bahwa Tuhan menjadikan alam dari tiada tidak mempunyai dasar syariat yang kuat. Tidak ada yang mengatakan bahwa Allah pada mulanya berwujud sendiri, yaitu tidak ada wujud selain dari diri-Nya. Dan kemudian barulah dijadikan alam. Ini hanyalah pendapat dan interpretasi kaum teolog. Menurutnya, alam dijadikan bukanlah dari tiada, melainkan dari sesuatu yang telah ada (Saefullah, 2013).

Terlepas dari perdebatan Al-Ghazali dengan para Filsuf, yang jelas proses kejadian alam yang diciptakan Allah dapat dilihat dalam Surat al-A'raf ayat 54 yaitu:

"Sesungguhnya Tuhan kamu ialah Allah yang telah menciptakan langit dan bumi dalam enam masa, lalu Dia bersemayam di atas 'Arsy. Dia menutupkan 
malam kepada siang yang mengikutinya dengan cepat, dan (diciptakan-Nya pula) matahari, bulan dan bintang-bintang (masing-masing) tunduk kepada perintahNya. Ingatlah, menciptakan dan memerintah hanyalah hak Allah. Maha Suci Allah, Tuhan semesta alam". (Q.S. al-A'raf: 54).

Kemudian dalam ayat lain Allah berfirman:

"Sesungguhnya dalam penciptaan langit dan bumi, silih bergantinya malam dan siang, bahtera yang berlayar di laut membawa apa yang berguna bagi manusia, dan apa yang Allah turunkan dari langit berupa air, lalu dengan air itu Dia hidupkan bumi sesudah mati (kering)-nya dan Dia sebarkan di bumi itu segala jenis hewan, dan pengisaran angin dan awan yang dikendalikan antara langit dan bumi; sungguh (terdapat) tanda-tanda (keesaan dan kebesaran Allah) bagi kaum yang memikirkan.” (Q.S. al-Baqarah: 164).

Berdasarkan ayat tersebut dapat dipahami alam itu ada bukan terjadi dengan sendirinya, melainkan ada yang menjadikan, yaitu Allah Swt. Hal ini membantah argumen yang dikemukakan oleh Filsuf Barat yang menyatakan bahwa alam itu terjadi secara alamiah (by nature) atau alam terjadi dengan sendirinya. Baik secara akal atau logika maupun wahyu dari Alquran dan Hadist, argumen Filsuf
Barat tersebut tidak dapat diterima. Secara logika, tidak mungkin alam ini ada jika tidak ada yang menjadikan. Walaupun yang mejadikan itu tidak tampak tetapi yang dijadikannya itu ada, konkret berbentuk benda, materi, dan sejenisnya. Sedangkan secara wahyu (naqli) selain dua ayat diatas yaitu QS. Al-Baqarah: 164 dan al-A'raf: 54 masih banyak ayat lain yang menceritakan tentang penciptaan alam, misalnya QS. Ibrahim: 32, 34, QS. Al-Hijr: 16, QS. An-Nahl 3-5, 8, 10-14, dan lain sebagainya (Saefullah, 2013).

Dari uraian di atas, dapat disimpulkan bahwa Filsuf Barat mengatakan bahwa alam terjadi dengan sendirinya seperti yang dikatakan oleh Thales bahwa alam ini berasal dari air, atau pendapat Leucippos pencetus teori atom, menjelaskan bahwa penciptaan alam semesta bermula dari beberapa atom yang berbeda bentuknya. Secara logika bagaimana mungkin sesuatu terjadi dengan sendirinya jika tidak ada yang menciptakan. Air dan atom yang mereka katakan sebagai dasar terjadinya alam tidak mungkin muncul dengan sendirinya kalau tidak ada yang menciptakan. Hal ini seperti halnya dengan benda-benda yang sering dilihat seperti computer, handphone, buku, pulpen, ataupun benda lainnya yang sering dijumpai. Benda-benda tersebut pasti ada yang membuat walaupun yang 
membuat tidak diketahui dimana dia berada. Sama halnya juga dengan sesuatu yang tidak terlihat dengan mata manusia seperti pulsa misalnya. Ketika orang membeli pulsa dia tidak melihat bentuknya tetapi ketika penjual mengirimkan pulsa ke nomor handphone ia akan mengetahui dan merasakan bahwa pulsa tersebut sudah masuk kedalam nomor handphone nya walaupun ia tidak melihat bentuknya. Apakah pulsa tersebut tercipta sendiri? Tentu saja tidak. Pulsa tersebut juga ada yang membuatnya.

Jika ada yang mengatakan bagaimana dengan Tuhan (Allah), apakah dia terjadi sendiri? Siapakah yang mencipta-Nya? Sebagai seorang yang muslim dan beriman maka jawaban tersebut dapat dijawab melalui Alquran yaitu pada surat al-Hadid ayat 3:

"Dialah Yang Awal dan Yang Akhir Yang Zhahir dan Yang Bathin; dan Dia Maha Mengetahui segala sesuatu" (Q.S. alHadid: 3).

Selanjutnya hadis yang diriwayatkan Imam Muslim berikut:

"Telah menceritakan kepadaku Zuhair bin Harb telah menceritakan kepada kami Jarir dari Suhail dia berkata; " Abu Shalih pernah menganjurkan kami yaitu, apabila salah seorang dari kami hendak tidur, maka hendaknya ia berbaring dengan cara miring ke kanan seraya membaca doa; Ya Allah, Tuhan langit dan bumi, Tuhan yang menguasai arasy yang agung, Tuhan kami dan Tuhan segala sesuatu, Tuhan yang membelah dan menumbuhkan biji-bijian, Tuhan yang menurunkan kitab Taurat, Injil, dan Al Qur'an. Sesungguhnya aku berlindung kepada-Mu dari kejahatan segala sesuatu, karena segala sesuatu itu berada dalam genggaman-Mu. Ya Allah, Engkaulah Tuhan Yang Awal, maka tidak ada sesuatu pun yang mendahului-Mu. Ya Allah, Engkaulah Tuhan Yang Akhir, maka tidak ada sesuatu setelah-Mu. Ya Allah, Engkaulah Yang Zhahir, maka tidak ada yang menutupi-Mu. Ya Allah, Engkaulah Tuhan Yang Bathin, maka tidak ada yang Samar dari-Mu. Ya Allah, lunaskanlah hutang-hutang kami dan bebaskanlah kami dari kefakiran." (HR. Muslim Nomor 4.888).

Berdasarkan ayat dan hadist di atas, maka dapat dijelaskan bahwa Allah itu adalah al-Awwal dan al-Akhir, artinya Allah disebut al-Awwal tidak ada sesuatupun sebelumnya, dan disebut dengan al-Akhir yaitu tidak ada sesuatupun setelahnya. Dan selaku orang yang beriman kepada Allah, maka orang ini wajib meyakini hal tersebut.

Selanjutnya pernyataan para Filsuf Islam yang mengatakan bahwa alam ini 
terjadi karena ada yang menciptakan, maka dengan demikian para Filsuf Islam tidak semata-mata atau tidak hanya menggunakan akalnya saja, tetapi juga menggunakan wahyu dari Alquran maupun Hadis Rasulullah Saw.

\section{Berkomunikasi dengan Alam Semesta}

Secara harfiyah dan batiniyah manusia tak bisa lepas dengan alam sekitar. Baik dalam bergaul, berkomunikasi, dan beribadah. Semua menjadi satu dimensi yang saling berkaitan. Dalam sains, diketahui bahwa jaring-jaring makanan, siklus daur air, dan gaya tarik gravitasi bumi ini merupakan kohesi diantara spektrum yang ada di alam raya ini. Yang telah diciptakan Allah kepada penduduk di alam ini. Bahwa, apa yang telah dikarunia oleh-Nya tak ada yang lepas dari pengamatannya. Segala sesuatu yang ada di bumi ini mampu berkomunikasi. Baik biotik maupun abiotik. Namun, cara dalam berkomunikasinya berbeda (www.aluswahtuban.com).

Para ilmuwan mengklaim telah menemukan bukti kuat pertama bahwa tanaman berkomunikasi dalam bahasa mereka sendiri melalui suara-suara yang terdengar oleh telinga manusia. Para ilmuwan di Universitas Bristol digunakan pengeras suara yang kuat untuk mendengarkan bibit jagung dan mendengar suara 'klik' yang berasal dari akar mereka.

Ketika mereka menghentikan akar dalam air dan memainkan suara yang kontinyu pada frekuensi yang sama, mereka menemukan tanaman itu tumbuh ke arah itu. Para peneliti mengatakan ini adalah bukti kuat pertama tanaman memiliki bahasa mereka sendiri yang bisa didengar manusia. Mereka menduga suara dan getaran mungkin memainkan peran penting dalam kehidupan tanaman.

Daniel Robert, seorang profesor Biologi di Bristol, mengatakan, "klik kecil yang sangat bising memiliki potensi untuk membentuk suatu saluran komunikasi antar akar". Penulis Monica Gagliano, dari University of Western Australia, mengatakan masuk akal bagi tanaman untuk memproduksi dan merespon getaran suara, karena memberikan mereka informasi tentang lingkungan sekitar mereka. Gelombang suara dapat melakukan perjalanan dengan mudah melalui tanah dan saling memberitahu ancaman seperti kekeringan.

Gagliano mengatakan penelitian ini membuka perdebatan baru tentang persepsi dan tindakan orang terhadap tanaman. Antara lain, kemungkinan untuk memperlakukan tanaman sebagai "makhluk hidup sesungguhnya" di samping manusia dan hewan. https://tekno. tempo.com).

Selain penelitian di atas, terdapat juga penelitian ilmiah yang diberitakan oleh 
majalah sains terkenal, Journal of Plant Molecular Biologist, menyebutkan bahwa sekelompok ilmuwan yang mengadakan penelitian mendapatkan suara halus yang keluar dari sebagian tumbuhan yang tidak biasa didengar oleh telinga biasa. Suara tersebut berhasil disimpan dan direkam dengan sebuah alat perekam tercanggih yang pernah ada.

Para ilmuwan selama hampir 3 tahun meneliti fenomena yang mencengangkan ini berhasil menganalisis denyutan atau detak suara tersebut sehingga menjadi isyaratisyarat yang bersifat cahaya elektrik (kahrudhahiyah) dengan sebuah alat yang bernama Oscilloscope. Para ilmuwan menyaksikan denyutan cahaya elektrik itu berulang lebih dari 1000 kali dalam satu detik. (http://zilzaal.blogspot.co.id).

Fenomena berkomunikasi alam semesta ini sudah tertera dalam Alquran Surat Al-Isra ayat 44 yaitu:

"Langit yang tujuh, bumi dan semua yang ada di dalamnya bertasbih kepada Allah. Dan tak ada suatupun melainkan bertasbih dengan memuji-Nya, tetapi kamu sekalian tidak mengerti tasbih mereka. Sesungguhnya Dia adalah Maha Penyantun lagi Maha Pengampun". (Q.S. al-Isra: 44)

Dalam Surat Israa': 44 di atas menunjukkan bahwa sesungguhnya, langit, bumi dan tumbuh-tumbuhan itu bertasbih kepada Allah, hanya manusia tak mengerti cara tasbih mereka. Namun tidak sampai disitu saja, seluruh alam semesta ini (makrokosmos) dan mikrokosmos juga bersujud merendahkan diri kepada Allah. Hal ini ditegaskan Allah dalam firman-Nya "Apakah kamu tiada mengetahui, bahwa kepada Allah bersujud apa yang ada di langit, di bumi, matahari, bulan, bintang, gunung, pohon-pohonan, binatangbinatang yang melata dan sebagian besar daripada manusia? Dan banyak di antara manusia yang telah ditetapkan azab atasnya. Dan barangsiapa yang dihinakan Allah maka tidak seorangpun yang memuliakannya. Sesungguhnya Allah berbuat apa yang Dia kehendaki" (Q.S. alHajj: 18).

Selain keterangan dari Alquran, dalam Hadist Nabi juga disebutkan bahwa alam semesta ini dapat berkomunikasi dengan manusia. Seperti hadis yang diriwayatkan oleh Imam Ahmad yaitu :

"Telah menceritakan kepada kami Husain telah menceritakan kepada kami Khalaf dari Abu Janib dari bapaknya, dari Abdullah bin Umar, Dahulu terdapat pelepah kurma di Masjid, tempat Rasulullah Shallallahu'alaihi wa Sallam menyandarkan punggungnya pada hari Jumat atau ketika terjadi kasus sehingga beliau musti bicara. Para sahabat kemudian 
mengajukan usul, "Bagaimana kalau kami membuatkan papan untukmu seukuran baginda berdiri, hai Rasulullah?": "Nggak masalah kalau kalian membuatnya." Jawab nabi. Maka para sahabat membuatkan beliau sebuah mimbar dengan tiga tingkat. Dia (Ibnu Umar) berkata; Minbar itulah yang kemudian Rasulullah Shallallahu'alaihi wa Sallam jadikan tempat duduk. Batang kurma tiba-tiba menangis kepada Rasulullah Shallallahu'alaihi wa Sallam sebagaimana sapi menangis. Lantas beliau memegang dan mengusapnya sehingga pohon itu tenang kembali". (H.R. Ahmad No. 5620)

Sebagai contoh yang nyata pada saat sekarang ini adalah peristiwa bencana alam yang sering kali terjadi termasuk juga di Indonesia seperti gempa bumi, letusan gunung, kebakaran hutan, banjir bandang, tenggelamnya kapal di laut, pemanasan global dan lain sebagainya. Peristiwa yang sering terjadi tersebut tidak lain adalah respon dari alam akibat perbuatan manusia yang tidak bertanggung jawab. Misalnya banyak manusia yang melakukan penebangan hutan secara ilegal, pembuangan limbah-limbah perusahaan tanpa penyaringan terlebih dahulu, dan pengeboman sungai atau laut ketika mengambil ikan. Perbuatan mereka tersebut tentunya akan merusak ekosistem yang ada di dalamnya. Allah Swt berfirman:

"Telah nampak kerusakan di darat dan di laut disebabkan karena perbuatan tangan manusia, supaya Allah merasakan kepada mereka sebahagian dari (akibat) perbuatan mereka, agar mereka kembali (ke jalan yang benar)". (Q.S. Ar-Rum: 41).

Dari beberapa uraian di atas, berdasarkan keterangan baik penelitian ilmiah, keterangan Alquran dan keterangan dari Hadis menunjukkan bahwa adanya interaksi komunikasi dengan alam semesta, baik alam semesta berkomunikasi dengan sesamanya, dengan manusia, dan dengan Allah, Tuhan pencipta Semesta Alam.

\section{SIMPULAN}

Filsafat merupakan salah satu akar dari ilmu komunikasi. Oleh karena itu filsafat komunikasi merupakan suatu pengetahuan yang menelaah secara mendasar mengenai keilmuan komunikasi dari historisnya, teori-teorinya, metodemetodenya, prinsip-prinsip metodologi yang digunakan, sampai pada semua hal yang terkait pada cakupan komunikasi.

Terdapat perbedaan yang mendasar tentang alam antara pandangan filsafat Barat dengan pandangan Filsafat Islam. Dalam pandangan Filsafat Barat, alam terjadi dengan sendirinya (by nature). 
Sedangkan dalam pandangan filsafat Islam, alam terjadi karena ada yang menjadikan yaitu Allah.

Segala sesuatu yang ada di bumi ini mampu berkomunikasi. Baik biotik (tumbuhan, hewan, manusia) maupun abiotik (tanah, air, udara, dan sinar matahari). Namun, cara dalam berkomunikasinya berbeda.

Berkomunikasinya alam ini dijelaskan melalui penelitian ilmiah dan dipertegas lagi dari Alquran dan Hadis. Hal ini membuktikan bahwa ternyata alam semesta (makrokosmos) melakukan komunikasi.

\section{DAFTAR PUSTAKA}

Adian, D.G. (2002). Menyoal Objektivisme Ilmu Pengetahuan. Jakarta: Teraju, 2002.

Alquran al-Karim

Anshari, E.S. (1987). Ilmu, Filsafat dan Agama. Surabaya: PT. Bina Ilmu, Cet.VII 1987.

Ardianto, E. \& Q-Anees, B. (2011). Filsafat Ilmu Komunikasi. Bandung: Simbiosa Rekatama, Cet. III, 2011.

Bakhtiar, A. (1997). Filsafat Agama. Jakarta: Logos, , (2010). Filsafat Ilmu. Jakarta: PT RajaGrafindo Persada,
Effendy, O.U. (2011). Ilmu Komunikasi Teori dan Praktek. (Bandung: PT.Remaja Rosdakarya.

Fiske, J. (2012). Introduction to Communication Studies/Pengantar Ilmu Komunikasi terj. Hapsari Dwiningtyas. Jakarta: Rajawali Pers..

Hadist riwayat Ahmad no. 5620.

Hadist riwayat Muslim, no. 4888.

http://aluswahtuban.com/berkomunikasi-denganalam (diunduh tanggal 4 Mei 2018, pukul 15.32).

http://zilzaal.blogspot.co.id/2012/02/tumbuhansaling-berkomunikasi (diunduh tanggal 4 Mei 2018, pukul 15.48).

https://tekno.tempo.co/read/409869/penelitiantumbuhan-pun-saling-berkomunikasi (di unduh tanggal 4 Mei 2018, pukul 15.37).

Kattsoff, Louis O. Pengantar Filsafat. Yogyakarta: Tiara Wacana Yogya, 2004.

Kholil, Syukur. Metodologi Penelitian Komunikasi. Bandung: Ciptapustaka Media, 2006.

Maarif, Z. (2006). Logika Komunikasi. Jakarta : PT RajaGrafindo Persada, Cet. II,

Mufid, M. (2009). "Etika dan Filsafat Komunikasi”. Jakarta.

Mulyana, D. (2001). Ilmu Komunikasi Suatu Pengantar. Bandung: Remaja Rosdakarya, Cetakan II, 2001.

Saefullah, U. (2013). Kapita Selekta Komunikasi: Pendekatan Budaya dan Agama. Bandung: Simbiosa Rekatama Media,

Salam, B. (1998). Pengantar Filsafat. Jakarta: PT. Bina Aksara, Cet. II,

Sujarwo \& Basrowi. (2009). Manajemen Penelitian Sosial. Bandung: CV Mandar Maju,.

Supriyadi, D. (2009) Pengantar Filsafat Islam: Konsep, Filsuf, dan Ajarannya. Bandung: CV Pustaka Setia, 2009.

Syarif, MM (Ed), (1993) Para Filosof Muslim.Bandung: Mizan.

Zain, A.Z. (1876). Mengungkap Rahasia Megahnya Alam Semesta. Albasith, 